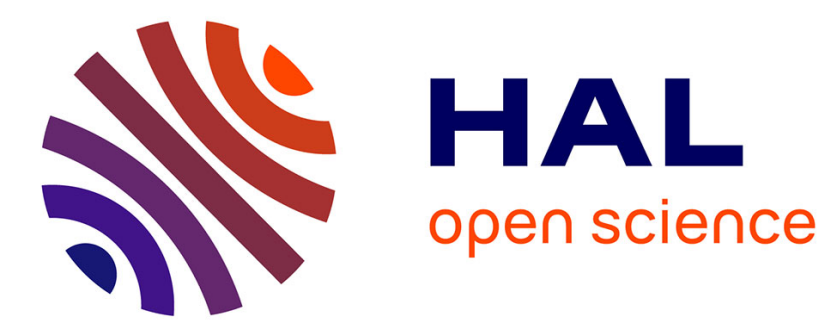

\title{
BEHAVIOUR OF URANIUM ALLOYS AT HIGH LOADING RATES
}

J. Buchar, S. Rolc, J. Pechá[math]ek, J. Krej[math]í

\section{To cite this version:}

J. Buchar, S. Rolc, J. Pechá[math]ek, J. Krej[math]í. BEHAVIOUR OF URANIUM ALLOYS AT HIGH LOADING RATES. Journal de Physique IV Proceedings, 1991, 01 (C3), pp.C3-197-C3-202. 10.1051/jp4:1991326 . jpa-00250468

\section{HAL Id: jpa-00250468 https://hal.science/jpa-00250468}

Submitted on 1 Jan 1991

HAL is a multi-disciplinary open access archive for the deposit and dissemination of scientific research documents, whether they are published or not. The documents may come from teaching and research institutions in France or abroad, or from public or private research centers.
L'archive ouverte pluridisciplinaire HAL, est destinée au dépôt et à la diffusion de documents scientifiques de niveau recherche, publiés ou non, émanant des établissements d'enseignement et de recherche français ou étrangers, des laboratoires publics ou privés. 


\title{
BEHAVIOUR OF URANIUM ALLOYS AT HIGH LOADING RATES
}

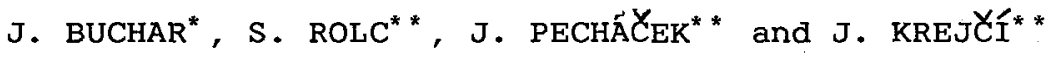 \\ *Department of Physics, University of Agriculture, zemæałlská \\ 1. 61300 Brno, Czechoslovakia \\ ** Institute of Physical Metallurgy, C.A.S, Žizkova 22, 61662 \\ Brno, Czechoslovakia
}

\begin{abstract}
Résumé: Le comportement d'uranium appauvri, uranium-molybdène, niobium, titane et rhenium a été étudié à grande vitesse de déformation sur barres d'Hopkinson. L'écaillage de ces matériaux a été également étudié. Une corélation entre la résistance à l'écaillage $\delta \mathrm{c}$ et les propriétés d'écoulement aété trouvée.
\end{abstract}

\section{ABSTRACT}

The mechanical behaviour of deplated uranium, uranium with molybdenum, niobium, titanium and rhenium was investigated under high strain rates. The Hopkinson split pressure bar was used.

The spallation of these materials was also studied. The correlation of the spall strength, $\sigma_{\mathrm{c}}$, with flow properties was found.

\section{INTRODUCTION}

It has long been known experimentally that a variety of metals show an increase in rate sensitivity when imposed strain rate is raised above $10^{3} \mathrm{~s}^{-1}$. This phenomen was also observed for uranium and its alloys [1-31.

The knowledge of this behaviour is very important in number of practical applications where the structure is loaded by the impact or detonation of explosive etc. During these events the material of most of structures is loaded in pressure. After the reflection of stress pulse at the free surface the tensile stress may and do occur. The material may be than damaged in form of spall fracture.

It means that the description of the material behaviour should involve both the characteristics of plastic flow and fracture properties.

The aim of the given paper consists in obtaining such data for depleted uranium and for four uranium alloys at strain rates higher than $10^{3} \mathrm{~s}^{-1}$.

\section{EXPERIMENTAL DETAILS}

The materials used in our experiments were depleted uranium, uranium $0.7 \mathrm{Ti}$, uranium 2.2 Mo, uranium $2.1 \mathrm{Nb}$ and uranium $1.9 \mathrm{Rh}$. The thermal treatment of these materials is described in (4). Specimen machined from each of these materials were tested in pressure at strain rates $10^{3}-10^{4} \mathrm{~s}^{-1}$ using Hopkinson Split Pressure Bar (HSPB) method a general description of this technique has been given elsewhere $5 \mathbf{l}$ 
The additional information on plastic flow and namely on fracture behaviour were obtained using plate-plate experiments indicated in Fig.1. This procedure was used for the study of uranium behaviour in [6].

The impact plate was mounted on the front of a projectile which was accelerated to the impact velocity with a $50 \mathrm{~mm}$ bore - diameter, compressed gas $\left(\mathrm{H}_{2}\right)$ gun. The samples were $20 \mathrm{~mm}$ in diameter, nominally $7 \mathrm{~mm}$ in thickness. The impact plates were $40 \mathrm{~mm}$ in diameter, nominally $8 \mathrm{~mm}$ in thickness. They were made from single crystals of sapphire with the crystal $z$ - axes oriented normal to the plane of impact.

The time-resolved motion of the sample back surface was recorded using a capacitor gauge method $\mathbf{1} 7 \mathbf{3}$.

\section{EXPERIMENTAL: RESULTS}

The effect of strain rate on the deformation behaviour at high rates of strain may be seen in Fig. 2 where the results obtained using HSPB method are displayed. The observed dependence of the flow stress on the strain rates at different level of plastic strain was fitted by an approximately linear dependence

$$
\sigma_{f}=\sigma_{B}+\alpha \varepsilon^{*}
$$

where parameters $\boldsymbol{\sigma}_{\mathrm{B}}$ and $\boldsymbol{\alpha}$ are given in Tab. 1. This linear dependence was obtained for many other materials [51. In 5 it was emphasized that this linear dependence is a consequence of the change in material response at strain rates above $\sim 10^{3} \mathrm{~s}$ with a change from thermal activation to phonon drag as the rate controlling mechanism. In view of the results presented e.g. in [8] it seems be more reasonable to interpret this behaviour as a transition zone between the regions where thermal activation and dislocation drag are rate controlling.

The deformation behaviour at high strain rates can be further obtained by analysing of the wave profiles determined at impact experiments depicted in Fig. 1. By using of the procedure outlined in $[6]$ we obtained results given in Fig. 3 where the dependence of Hugoniot stress, $p_{H}$ on the maximum strain rate, $\varepsilon_{m}^{*}$, in the plastic wave was displayed. It may be seen that this method enables to obtain much more higher values of strain rates than HSPB method. If we extrapolate the values of $\boldsymbol{\sigma}_{\mathrm{c}}$ to these strain rates we may see that the values of $\mathrm{p}_{i}$ are higher. There is also no connection between $\sigma_{f}\left(\varepsilon^{*}\right)$ and $p_{H}\left(\varepsilon_{m}^{*}\right)$. The dependences $p_{H}\left(\varepsilon_{m}^{*}\right)$ can be fitted by

$$
P_{H} \sim \varepsilon_{m}^{* n}
$$

where $\mathrm{n}$ is very closed to the value of $1 / 4$ as follows from the theory described in r93. Nevertheless to this fact the order of tested materials from the point of their rezistivity to the plastic flow remains unchanged.

The planar impact of sapphire on samples with free surfaces opposing the impact interface lead to the internal dynamic fracture-spall.

The resistivity of the tested materials to the spall fracture were evaluated using the spall strength, $\boldsymbol{6}_{\boldsymbol{c}}$. The value of $\mathbf{6}_{\mathbf{c}}$ was inferred from the free surface velocity time record using pull back signal. The calculation of a spall strength from the pull back signal is generally dependent on the material response $10 \mathbf{d}$. The model of material behaviour described in [61 was accepted. The calculated spall strength data were correlated with the peak free surface velocities. These velocities correspond to the strain rates at spall $\mathbf{6 1}$. The obtained results are given in Fig. 4. If we compare our data with earlier data $\mathbf{6 l}$ we may see that our values of $\boldsymbol{\sigma}$ are slightly lower. 
The materials with higher values of flow stress or Hugoniot stress, respectively, the spall strength is less sensitive to the increase of the strain rate. At sufficiently high strain rates there is nearly no difference in spall strength data for the materials under consideration.

The dependence of $\sigma_{c}$ on $\varepsilon^{\circ}$ can be expressed by

$$
\sigma_{c}=\left(9 \operatorname{xgcK}{ }_{I C}^{2} / 16\right)^{1 / 3} \varepsilon^{.1 / 3},
$$

where $\rho c$ is the acoustic impedance and $\mathrm{K}_{\mathrm{IC}}$ denotes the fracture toughness. The theory leading to the given equation [11] thus predicts that for uranium alloys with higher dynamic strength $\left(\sigma_{f}, p_{H}\right)$ the $\mathrm{K}_{\mathrm{IC}}$ should decrease with strain rate more rapidly than e.g. for unalloyed uranium. This conclusion is unexpected owing to knowledge on fracture behaviour of some high strain steels, aluminium alloys etc. where $\mathrm{K}_{\mathrm{IC}}$ is not too significantly dependent on the $\varepsilon^{\circ}$.

\section{DISCUSSION AND CONCLUSIONS}

The results presented above show that the behaviour of the given materials at high rates of strain exhibits the same features like many other materials tested up to known. The uranium alloys with higher strength exhibit lower increase of strength properties with the increase of $\varepsilon^{\circ}$.

The spall strength of these materials is also less sensitive to the strain rate in comparison e.g. with depleted uranium. If we use these materials for design of structural parts which are exposed to impact loading we may found that fracture behaviour at some critical loading conditions is independent on the alloying. This conclusion was experimentally verified for projectiles. At impact velocity below $1400-1600 \mathrm{~m} / \mathrm{s}$ the best resistivity to the fracture damage exhibited uranium - Nb or uranium - Rh alloys. At impact velocity above $\sim 1700 \mathrm{~m} / \mathrm{s}$ we observed nearly the same fracture strength for all uranium alloys tested in the given paper.

\section{REFERENCES}

11 MAIDEN, C.J., J.Mech. Phys. Solids 7 (1959) 106.

[2] BOYD, G.A.C., HARDING, J., BLEASDALE, P.A., DUNN, K. and TURNER, G. :Journal de Phys.46 (1985) 487.

I3] SHAIBANI, S.J., HARDING, J., DUNN, K., TURNER, G.I.: Strain Rate Effects in Fast-Gas-Cooled Uranium-Titanium and Uranium - Niobium Alloys.

In: Impact loading and dynamic deformation of materials (G.Y Chiem, H.D.Kunze and L.W.Meyer, Eds.) DGM Informationsgesellschaft Verlag, 1987, pp. 623-630.

[4] BUCHAR, J.: Deformation behaviour of Uranium and its alloys. Res.Rep. VZ792/893 Institute of Metallurgy Brno, 1988.

[5] BUCHAR, J., BÍLEK, Z., DUŠEK, F.: Behaviour of metals under extremaly high strain rates. Trans Tech Pub1, Switzerland 1986

(6) GRADY, D.E.: Steady-Wave Risetime and Spall Measurements on Uranium (3-15 GPa).In: Metallurgical Applications of Shock Wave and High Strain Rate Phenomena (L.E.Murr, K.P.Staudhammer, M.A.Meyers, Eds.) Marcel Dekker, New York and Basel, 1986, pp. $763-780$.

l7 BUCHAR, J.: Acta Technica ČSAV, No3 (1989), 321.

(8) FOLLANSBEE, P.S.: High-Strain-Rate Deformation of FCC Metals and Alloys. ibid [6], pp. 431-480.

(91 ASAY,J.R., CHHABILDAS,L.C., WISE,J.L.: Shock wave propagation in 
berylium. In: Shock Waves in Condensed Matter-1981 (W.J. Nellis et al., Eds.) AP, New York 1982, pp. 427-431.

I10】 ROMANCHENKO, V.I., STEPANOV, G.V. Zh.Ph.Mekh.Tekh. Fiz.4 (1980), 141

I11] KIPP, M.E., GRADY, D.E., CHEN, E.P.: Int. J. Fracture 16 (1980) 471.

Table 1 Deformation characteristics

\begin{tabular}{|c|c|c|c|}
\hline Material & $\epsilon \quad[\%]$ & $\sigma_{B} \backslash \mathrm{MPa}$ & $\propto[\mathrm{kPa} s \mathbf{l}$ \\
\hline \multirow[t]{4}{*}{ Depleted̂ Uranium } & 0.2 & 670 & 37.1 \\
\hline & 0.5 & 695 & 36.6 \\
\hline & 1.0 & 730 & 36.6 \\
\hline & 2.0 & 750 & 36.3 \\
\hline \multirow[t]{4}{*}{ Uranium - Nb } & 0.2 & 1210 & 25.1 \\
\hline & 0.5 & 1230 & 25.0 \\
\hline & 1.0 & 1250 & 25.0 \\
\hline & 2.0 & 1300 & 24.8 \\
\hline \multirow[t]{4}{*}{ Uranium - Ti } & 0.2 & 900 & 35.2 \\
\hline & 0.5 & 920 & 35.0 \\
\hline & 1.0 & 950 & 35.0 \\
\hline & 2.0 & 970 & 34.8 \\
\hline \multirow[t]{4}{*}{ Uranium - Mo } & 0.2 & 1050 & 30.0 \\
\hline & 0.5 & 1080 & 30.0 \\
\hline & 1.0 & 1100 & 29.6 \\
\hline & 2.0 & 1150 & 29.4 \\
\hline \multirow[t]{4}{*}{ Uranium - Rh } & 0.2 & 1180 & 26.0 \\
\hline & 0.5 & 1200 & 25.8 \\
\hline & 1.0 & 1210 & 25.6 \\
\hline & 2.0 & 1220 & 25.5 \\
\hline
\end{tabular}

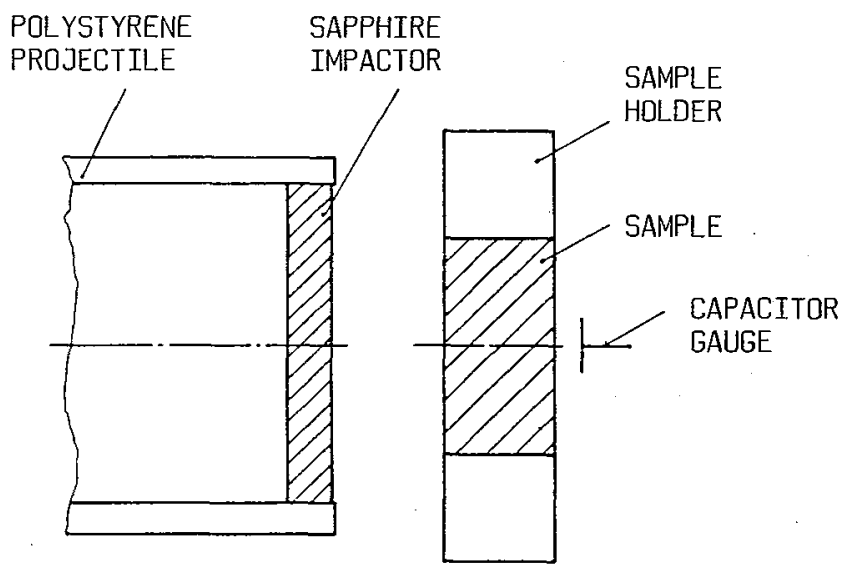

Fig. 1 : Experimental set-up 


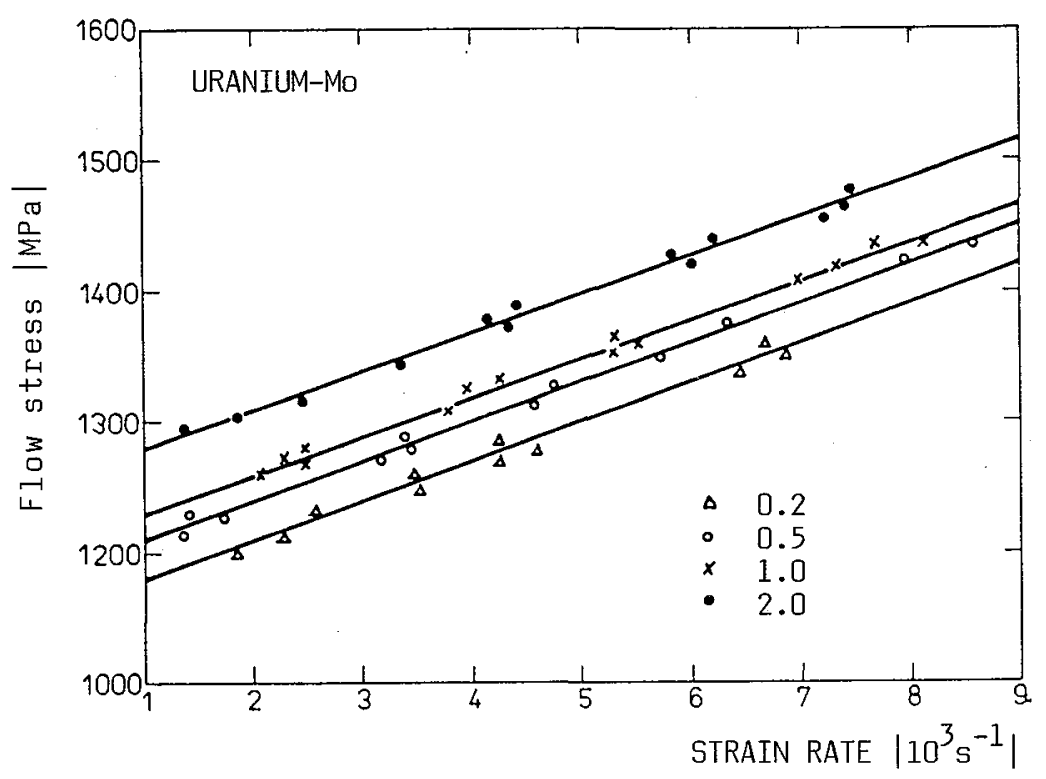

Fig. 2 : The dependence of the flow stress on the strain rate

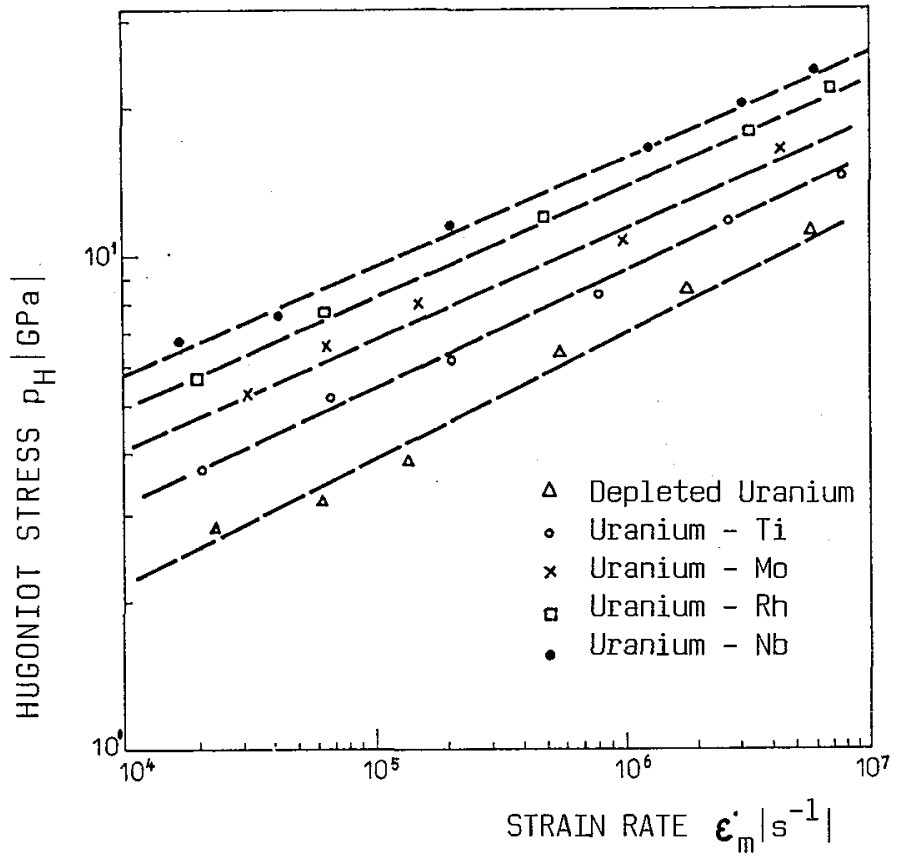

Fig. 3 : The effect of the strain rate on the Hugoniot stress 


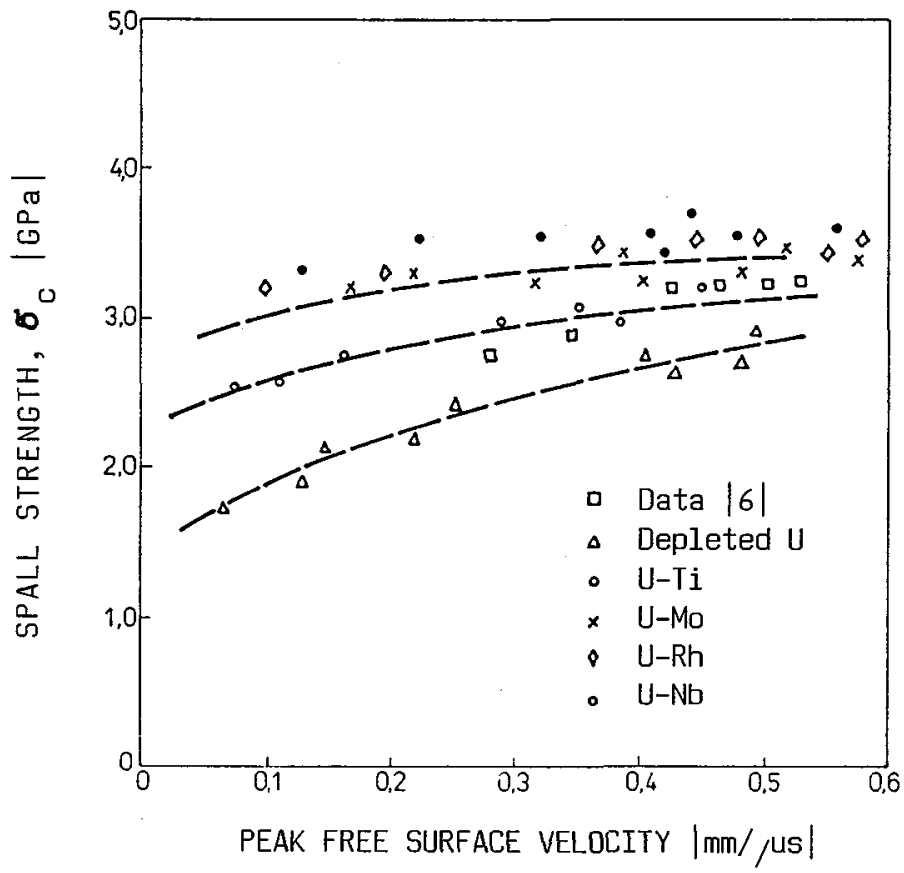

Fig. 4 : Spall strength data for the tested materials 